\title{
Alternatives in flood protection: the effect of decentralized measures in the Upper Flöha watershed (Southeastern Germany)
}

\author{
Ch. Reinhardt, J. Bölscher, M. Ramelow, R. Wenzel \& A. Schulte \\ Institute of Geographical Sciences, Freie Universität Berlin, Germany
}

\begin{abstract}
In the German-Czech border regions throughout the Ore Mountains, storm runoff frequently causes severe damage in headwater areas and lower reaches. The fact that settlements along smaller tributaries and towns near the receiving water are affected simultaneously requires a flood control concept with measures applied throughout the entire drainage area. Modern concepts of flood protection offer a large number of potential natural measures, such as a number of small, decentralized retarding basins, river revitalization, afforestation of flood plains or landuse changes. The study presented here is part of the Interreg-IIIA research project "DINGHO". Its aim is to show how decentralized measures can contribute to improving flood protection in the Upper Flöha catchment. The advantages and limits of such natural flood protection measures will be illustrated.

The study area extends between the large Rauschenbach reservoir and the town of Olbernhau (Saxony), including two main tributaries - the Natzschung and Schweinitz rivers. In a first step the local potentials were investigated on the basis of GIS analyses and field surveys. The second step included the assessment of the efficiency of the decentralized measures in different scenarios using the rainfall-runoff models NASIM and WaSiM-ETH.

Particularly in higher regions with gentle slopes (above $\sim 700 \mathrm{~m}$ a.s.l.), wide areas along the river channels can be used for water retention in small, decentralized retarding basins. In addition, some areas can be reforested, since they have recently recovered from the $\mathrm{SO}_{2}$ pollution, which affected the area until the late 1980s. By contrast, potentials for river channel renaturation are strongly limited.
\end{abstract}


The modelling results clearly indicate that small retarding basins would reduce peak discharges with a 100 -year return period by up to $48 \%$ at some tributaries and 10\% downstream in Olbernhau. River restoration measures do not show any significant effect. Reforestation of forest decline areas can reduce peak discharge by about $13 \%$.

Hence an effective improvement of flood protection in the Upper Flöha catchment can be achieved through the application of decentralized measures. The reduction of flood peaks includes the Flöha River itself, tributaries and headwater areas.

Keywords: flood protection, decentralized measures, retarding basins, renaturation, reforestation of floodplains, landuse changes, rainfall-runoff modelling.

\section{Introduction}

As shown by the August 2002 extreme flood and numerous local events described by Büttner et al. [1], losses arising from flooding caused by storm runoff frequently occur throughout the low mountain ranges of Southeastern Germany (Free State of Saxony) and especially in the Ore Mountains in the German-Czech border regions. Further deterioration has also to be considered because an increase in the frequency of storm events in the months July and August as a result of global climatic changes was predicted for Saxony (SMUL [2]). The strategy for adaptation and mitigation of flood risks in the Free State is based on a combination of precaution (early warning systems, education, etc.) and spatial planning (e.g. identification of flood generating areas, designation of inundation areas), widespread retention in catchment areas (e.g. funding of agricultural techniques that facilitate infiltration), as well as technical flood protection. To improve technical flood control, 47 individual concepts with a large number of proposals for defence construction projects were developed for first order rivers (Socher et al. [3]). By contrast, further research has to be carried out for second order rivers - where, according to the Water Act of Saxony, municipalities are responsible for water management and flood control - because protection plans are lacking in many cases.

Against this background, potentials for an improvement of flood protection in the Upper Flöha watershed were investigated in the framework of the "DINGHO" research project, which received funding from the Interreg-IIIA program of the European Union. The aims of the project are to reveal the contribution of decentralized and natural measures for flood control in municipalities along second order rivers (headwater areas) as well as downstream at the river Flöha. The studies focused on two different fields: 1.) measures along rivers and creeks (small retarding basins, river renaturation, afforestation of floodplains) and 2.) widespread landuse and utilization changes.

\subsection{The principle of decentralized flood protection}

Since the early 1990s numerous studies on the effect of decentralized measures in different river basins have been published in the German literature (e.g. 
Wegner [4], Assmann et al. [5], Marenbach and Koehler [6], Röttcher and Tönsmann [7], Röttcher [8], as well as summaries edited by Röttcher et al. [9] or published by DWA [10]). The concept is based on the idea that in mesoscale river basins $\left(\leq 1000 \mathrm{~km}^{3}\right)$ a system of numerous small and distributed flood control measures can be established throughout the entire drainage area (fig. 1) instead of large defence constructions downstream (e.g. a large retarding basin). By distributing the measures an improvement of flood protection can be achieved that includes settlements in headwater areas as well as at the receiving water.
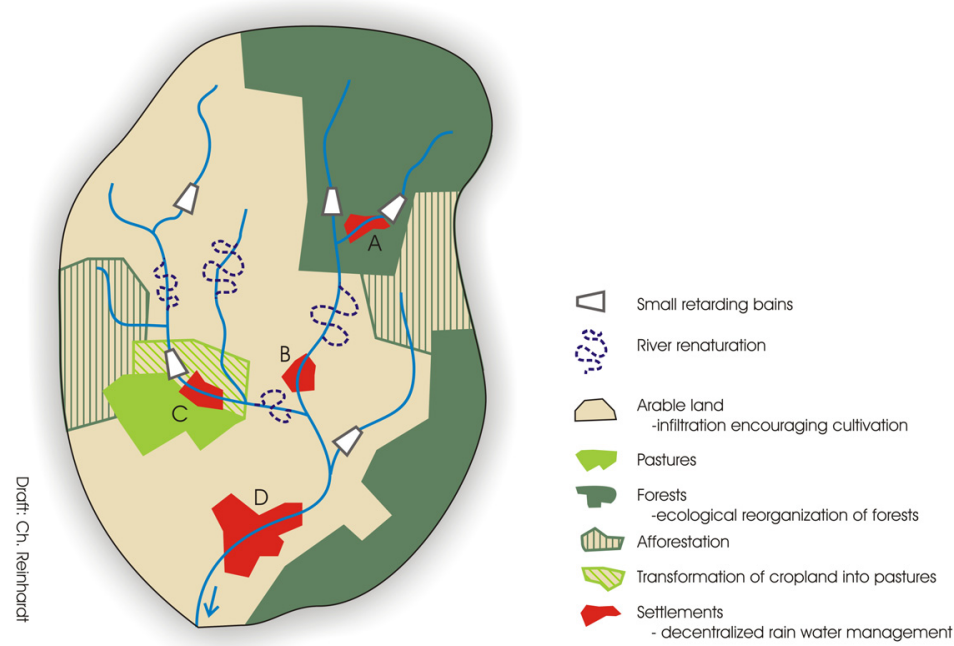

Figure 1: The principle of decentralized flood protection, illustrated for selected measures in a small watershed. A-C: municipalities located upstream and in headwater areas, D: municipality at the lower course of the studied river.

The large number of published decentralized measures can be classified in three different groups:

1) Measures at and around rivers: e.g. systems of small retarding basins with a maximum storage capacity of 50,000 - 100,000 $\mathrm{m}^{3}$ each, retention behind obstacles (e.g. cross-valley road embankments), retention in existing ponds, river renaturation, reforestation of floodplains

2) watershed-wide retention e.g. afforestation, ecological reorganization of forests, conversion of arable land into pastures, infiltration promoting cultivation of croplands

3) Settlements: e.g. decentralized rain water management, renaturation of paved urban areas

Depending on type and number of measures as well as the local characteristics of the drainage area under investigation, the predicted reduction 
of peak discharges for periodic floodings (return period of 100 years) ranges from only 1 to almost 50 percent (Bauna river, Röttcher and Tönsmann [7]). The previously published data show clearly, that decentralized measures can be very efficient elements in flood control concepts. However, the large range of calculated peak reductions demonstrates that existing results cannot be assigned completely to other drainage areas. Different drainage structures lead to an individual combination and overlap of flood waves, so that separate investigations for any other river basin are required during the planning process.

Another important fact that has to be considered in the framework of flood control, concepts is the potential impact of the planned measures on landscape and ecosystems. Whereas large technical constructions strongly influence natural systems along rivers, the impact of decentralized measures is much lower. The head of water in retarding basins is restricted to a few metres, so impoundage remains short and negative influences on the natural scenery are limited. Moreover, the renaturation of river systems and associated measures lead to an activation and enforcement of natural retention in floodplains, ecological demands being satisfied at the same time. Landuse and utilization changes may encourage infiltration and cause widespread improvements of the natural water balance. Owing to these synergistic effects, decentralized measures can be understood as part of an integrated watershed management, conforming to requirements of flood protection as well as nature conservancy.

In the international literature similar approaches can be found in the context of watershed management and rainwater harvesting (cf. Brooks et al. [11], Lancaster [12], Westervelt [13]). However, in many cases the basic ideas, aims and the application of the concepts are not completely identical.

\section{Study area}

The study area is located $50 \mathrm{~km}$ southwest of Dresden in the central Ore Mountains and includes the Upper Flöha River between the large Rauschenbach reservoir and the city of Olbernhau (fig. 2). With its two main tributaries, the Natzschung and Schweinitz rivers, the watershed extends over an area of 228 $\mathrm{km}^{2}$. Because time series of the gauge in Olbernhau for the calibration of the rainfall-runoff models have been available solely since 2005, the modelling area had to be enlarged downstream towards the Pockau 1 gauge $\left(315 \mathrm{~km}^{2}\right)$. The low mountain geomorphology is characterized by two main landscape types. Headwater areas, which are located in higher regions, are developed plateau-like with wide valleys and gentle slopes (remnants of peneplains). By contrast, lower reaches are strongly dissected by steep V-shaped canyons, incised during the Quaternary.

Approximately two-thirds of the area under investigation is covered by forests, including coniferous (28\% of the total catchment area), broad-leaved $(6 \%)$ and mixed forest (8\%). Another $24 \%$ are characterized by a transitional woodland-shrub-like vegetation. In the Ore Mountains this vegetation type is a result of the $\mathrm{SO}_{2}$-pollution-related forest decline, which affected higher mountain reaches until the late 1980 s and early 1990s. Because these regions are 
recovering gradually they are subject to reforestation with spruce and secondarily to natural succession with birch and rowan. The remaining third of the total area is used for agriculture (cropland, pastures), whereas settlements cover 3 percent only.

\section{Rainfall-runoff modelling}

The analysis of the effects of decentralized measures in the study area is based on the application of distributed rainfall-runoff models. Depending on the type of measures under investigation, two different model systems were used. Measures along rivers (retarding basins, renaturation and afforestation of floodplains) were investigated using the model system NASIM, designed by Hydrotec (Aachen, Germany). As shown in figure 2, the total modelling area was subdivided into two independent components - the Natzschung watershed model (Bölscher [14]) and the Schweinitz/Flöha model (Reinhardt [15]). To assess the total effect of all measures in Olbernhau, the models were connected at the gauging station of Rothenthal (fig. 1). By contrast, the influence of landuse and utilization changes was investigated for the entire study area by Ramelow [16] using the model system WaSiM-ETH.

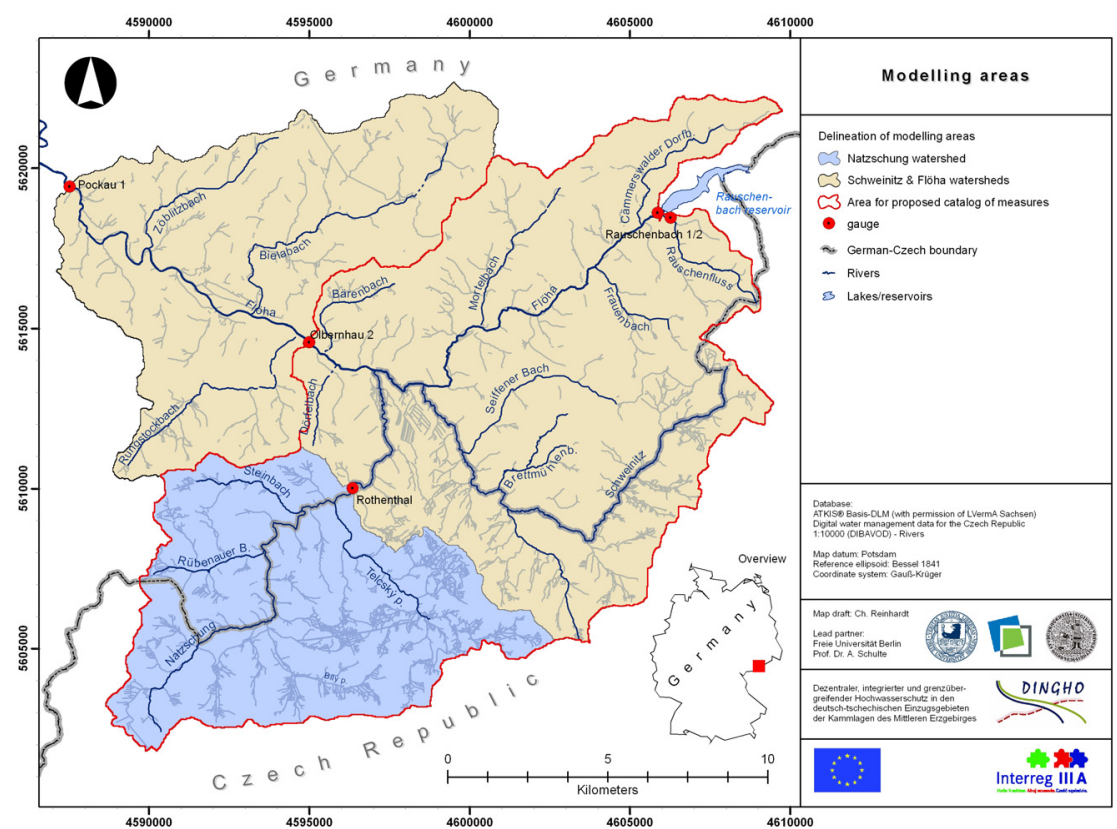

Figure 2: $\quad$ The Upper Flöha basin between the Rauschenbach reservoir and the Pockau 1 gauge, including the modelling areas Natzschung and Schweinitz/Flöha. The area for the proposed measures (dark grey outline) is located upstream of the town of Olbernhau (Olbernhau 2 gauge). 
To calibrate the hydrological models, time series of discharge for the period 2002-2006 from Rothenthal/Natzschung, Pockau 1/Flöha and Olbernhau 2/Flöha gauges were used. On the basis of the calibrated models and statistical rainfall amounts, a design flood event with a return period of 100 years was simulated in a second phase, which serves as a reference for assessing the efficiency of the planned measures. During the third working phase, different scenarios for decentralized measures were implemented in the watershed models. The process of scenario development incorporated various results from field studies, e.g. potential location and storage capacity of the retarding basins, which were determined by geodetic surveys, or river sections for renaturation which are based on detailed water structure surveys.

\section{Results and discussion}

\subsection{Potentials for decentralized measures}

Depending on the class of measures, the potentials in the study area differ strongly. In the Natzschung watershed (fig. 2) 19 locations for small retarding basins were identified, including 3 artificial ponds which can be used for flood protection by lowering the existing water level. Additionally 13 sites throughout the model area of Schweinitz/Upper Flöha were considered, resulting in a total of 32 basins with a cumulated storage capacity of nearly $800,000 \mathrm{~m}^{3}$. The storage level in the retarding basins is limited to $4-5 \mathrm{~m}$. To allow the constructions to be fully integrated into the natural scenery, earth dams with a cross section gradient of 1:3 were assumed. Discharge is controlled by unregulated throttles with diameters of $300-1,800 \mathrm{~mm}$, which can be constructed as round concrete pipes.

According to the water structure surveys and the mapped state of the rivers, only very few short sections can be considered for renaturation. By contrast, potentials for the afforestation of floodplains can be found along almost all water courses, so these measures were considered along all river sections, which are located outside settlements.

As far as landuse changes are concerned, these measures can be realized in the long term only. For the area under investigation potentials can be found mainly in an ecological reorganization of forest systems from spruce cultures to natural mixed forests as well as the afforestation of regions that were affected by heavy forest decline until the late 1980s. To understand the general hydrological effects, two additional scenarios for a complete forest cover of the entire study area and the transformation of cropland into pastures around settlements were calculated.

\subsection{Hydrological effects}

The proposed scenarios show a strong variability in their hydrological effects, depending mainly on the type of measures and the reference location. For municipalities in headwater areas along second order rivers, a high reduction of 
peak discharges of the reference flood event (100-year recurrence interval) by the construction of retarding basins can be registered, e.g. in Rübenau $(45 \%)$, Načetin/Czech Republic (48\%, Bölscher [14]) as well as in Seiffen (28\%, Reinhardt [15]). For the city of Olbernhau, in the lower reaches of the study area, the model reveals a possible reduction of $10 \%$ (fig. 3) when all 32 retarding basins are included. Modelled separately the 19 retarding basins throughout the Natzschung watershed would lead to a reduction of $6 \%$ in Olbernhau, whereas the 13 sites throughout the modelling area of Schweinitz/Flöha may reduce peak discharges by $4 \%$.

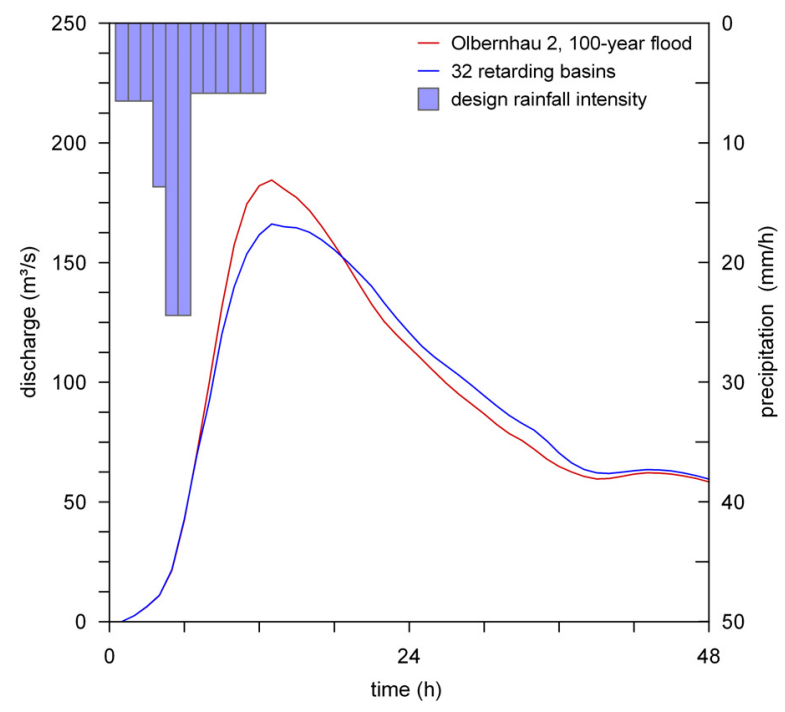

Figure 3: Hydrographs showing the effects of the proposed decentralized retarding basins for the city of Olbernhau at the river Flöha.

In contrast to the clear effects of the retarding basins, the considered river renaturations do not result in a significant reduction of flood peak discharges neither for Olbernhau nor municipalities in headwater areas. However, low efficiency is not a general problem of renaturation, but rather caused by the limited number of river sections in the study area, that are suitable for such measures. Distinct effects can be expected from the afforestation of floodplains, which result in increased roughness coefficients along the rivers. Under consideration of afforested floodplains in the watersheds of Schweinitz and Flöha, a peak reduction of $4.3 \%$ and a lag of about 2 hours can be achieved for Olbernhau. The main retention effects occur along the Flöha River (3.5\%), where the bed slope is low and the floodplain wide, whereas afforestation along tributaries leads to a further decrease caused by a slightly stronger separation of flood waves in the model. When the Natzschung is included, no further increase of the effect in Olbernhau can be noticed, although Bölscher [14] observed a significant reduction at the Rothenthal gauging station in his model of the Natzschung watershed. 
Because significant hydrological effects for retarding basins as well as afforestation of floodplains were registered, the combination of both measures was also examined. According to the modelling results in Olbernhau, a peak discharge reduction of $6.6 \%$ can be achieved when combined measures in the Natzschung watershed are considered, whereas measures in the watersheds of Flöha and Schweinitz would lower flood peaks by $8.2 \%$. Combined measures in both modelling areas would result in a reduction of $12.8 \%$ in Olbernhau (fig. 4).

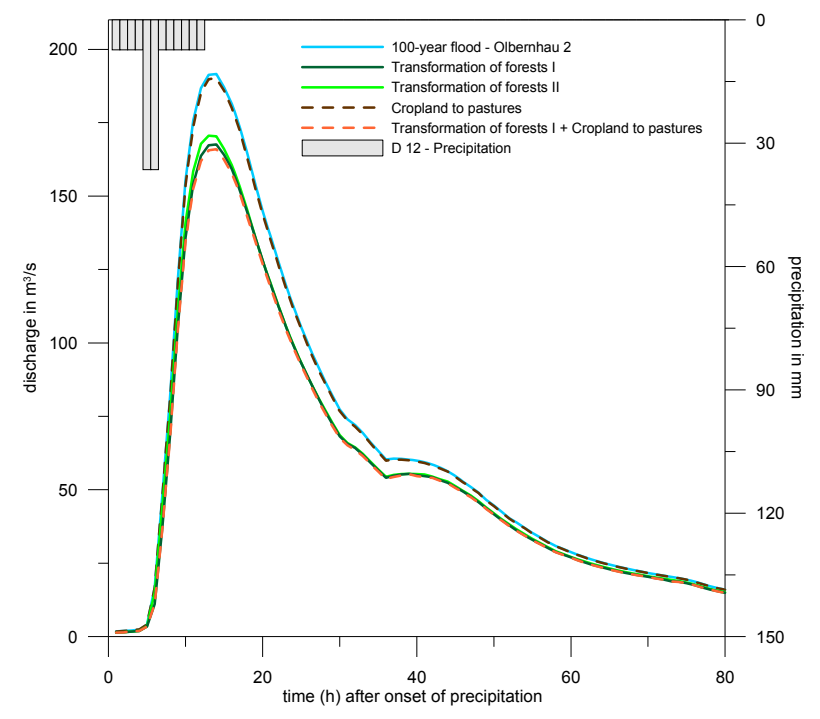

Figure 4: Hydrographs showing the effects of combined measures for the city of Olbernhau.

The modelled landuse scenarios reveal reduction effects similar to those achievable by a combination of retarding basin and floodplain afforestation. As far as the ecological conversion of existing forests from spruce monocultures into natural mixed forests is concerned, a decrease of the modelled flood peak by $15 \%$ can be observed. Moreover, a flood peak reduction of $13 \%$ occurred, when recently declined and afforested areas (transitional woodland-shrub vegetation) were replaced by mixed forests (fig. 5). By contrast, the transformation of croplands around selected settlements in the study area into pastures does not indicate any significant supralocal effects. However, when assessing the effect of landuse changes it has to be considered that in regions with intensive agriculture and forestry a long period is required for planning and the transformation process. Against this background the systematic afforestation of forest decline areas and the development of mixed forests offer chances to improve flood protection as well as natural habitats without high additional investments. 


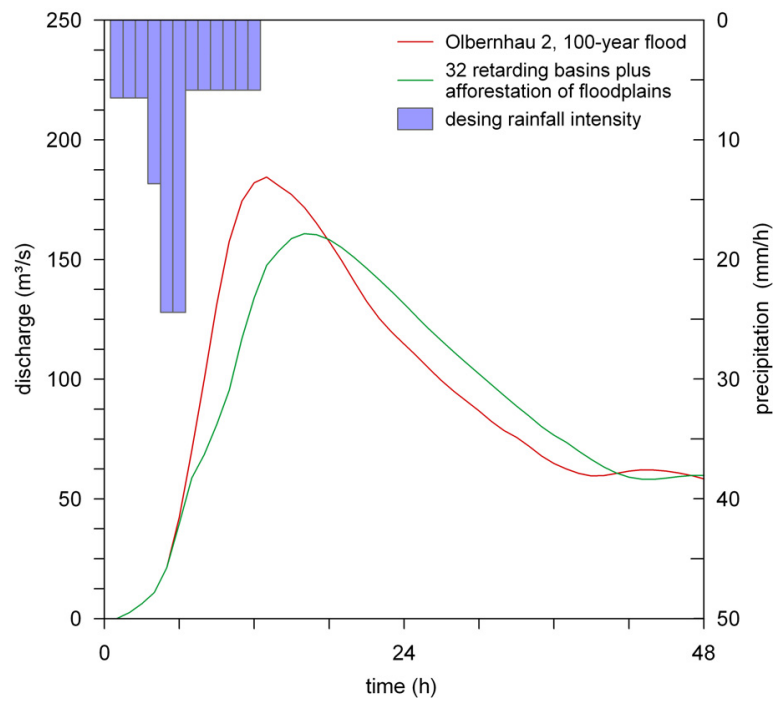

Figure 5: Hydrological effects of landuse changes on flood peaks in Olbernhau for different model scenarios.

\section{Conclusions}

The modelling results clearly indicate to what extent decentralized measures contribute to an improvement of flood protection in the area under investigation (tab. 1). Beneficiaries of small, natural retarding basins include settlements along the Flöha tributaries, where very high flood peak reductions of up to $48 \%$ were observed by the application of the rainfall-runoff models. Beyond tributaries and headwater areas the effects along the receiving water (Flöha) are lower, but still reach $10 \%$ in Olbernhau. In combination with reinforcement of the retention along the river by afforestation of floodplains, peak discharges can be decreased by $12.8 \%$. Similar reductions can be achieved by afforestation of declined forest areas, when the newly established tree population has developed into a closed forest system.

On the whole, we may conclude that decentralized measures offer good opportunities to bring together flood protection and ecological aspects. Apart from the recognized hydrological effects, expressed by the modelled flood peak reductions, the impact on the natural system is very low. On the contrary, various measures even lead to an improvement of the ecological state in mesoscale river basins. However, their applicability as flood protection elements strongly depends on the potentials and resources in the examined watershed, e.g. total storage capacity, number of river sections for renaturation, access to areas for landuse changes, etc. If large potentials are available, an effective and natural flood protection can be established by decentralized measures. 
Table 1: $\quad$ Summary of predicted flood peak reductions.

\begin{tabular}{|l|l|}
\hline Measures & $\begin{array}{l}\text { Flood peak } \\
\text { reduction } \\
(\%)\end{array}$ \\
\hline $\begin{array}{l}\text { Small retarding basins } \\
\text { Načetin } \\
\text { Rübenau }\end{array}$ & 48 \\
Seiffen & 45 \\
Obernhau & 28 \\
\hline $\begin{array}{l}\text { Afforestation of floodplains } \\
\text { Olbernhau }\end{array}$ & 9.9 \\
\hline $\begin{array}{l}\text { Combination of retarding basins and afforestation } \\
\text { of floodplains } \\
\text { Olbernhau }\end{array}$ & 4.2 \\
\hline $\begin{array}{l}\text { Transformation of forests I: (coniferous forest to } \\
\text { mixed forest) } \\
\text { Olbernhau }\end{array}$ & 12.8 \\
\hline $\begin{array}{l}\text { Transformation of forests II: (transitional } \\
\text { woodland-shrub to mixed forest) } \\
\text { Olbernhau }\end{array}$ & 15 \\
\hline $\begin{array}{l}\text { Conversion of cropland in pastures } \\
\text { Olbernhau }\end{array}$ & 13 \\
\hline
\end{tabular}

\section{References}

[1] Büttner, U., Fügner, D. \& Winkler, U., The flood on 5 and 6 July 1999 in the region of Marienberg in the Ore Mountains (Saxony). Hydrologie \& Wasserbewirtschaftung 45(3), pp. 102-111, 2001. In German with an English summary.

[2] SMUL (Saxon State Ministry of the Environment and Agriculture), Climate change in Saxony - state of research and perspectives, Dresden, pp. 1-111, 2005. In German.

[3] Socher, M., Dornack, S. \& Defér, E., Flood-protection concepts in the Free State of Saxony - an introduction. Hydrologie \& Wasserbewirtschaftung $\mathbf{5 0}$ (6/2006), pp. 303-308, 2006. In German.

[4] Wegner, H., Decentralized flood control. Wasser \& Boden 44 (1/1992), pp. 6-10, 1992. In German with an English summary.

[5] Assmann, A., Gündra, H., Schukraft, G. \& Schulte, A, Decentralized and integrated flood protection planning for the Upper Elsenz. Wasser \& Boden 50(8), pp. 15-19, 1998. In German with an English summary.

[6] Marenbach, B. \& Koehler, G., Local and supralocal effects of central and decentralized measures of flood protection. Wasser \& Boden 55 (7/8), pp. 22-26, 2003. In German with an English summary. 
[7] Röttcher, K. \& Tönsmann, F., Potentials and limitations of a decentralised flood protection approach in the German Mittelgebirge: the Bauna River case study. Wasser \& Boden 53(10), pp. 29-34, 2001. In German with an English summary.

[8] Röttcher, K., Decentralized and central water retention measures for flood protection - exemplified investigations at the Erpe River. Wasser und Abfall 5, pp. 11-15, 2005. In German.

[9] Röttcher, K., Koehler, G., Kleeberg, H.-B. (eds), Decentralized flood protection, Forum für Hydrologie und Wasserbewirtschaftung 17.06, pp. 1182. In German.

[10] DWA (German Association for Water, Wastewater and Waste), DWAtopics - Decentralized measures for flood reduction, Hennef, pp. 1-110, 2006. In German.

[11] Brooks, K., Ffolliot, P.F., Gregersen, H.M., DeBano, L., Hydrology and the management of watersheds, Iowa State University Press, Ames, pp. 1-502, 1997.

[12] Lancaster, B., Rainwater Harvesting for Drylands and Beyond, Volume 2: Water Harvesting Earthworks, Rainsource Press, Tucson, pp. 1-417, 2008.

[13] Westervelt, J., Simulation Modelling for Watershed Management, Springer, New York, Berlin, pp. 1-190, 2001.

[14] Bölscher, J.: The analysis of potentials for decentralized water retention in the Natzschung watershed (Central Ore Mountains) using the rainfallrunoff model NASIM, PhD thesis, Department of Earth Sciences Freie Universität Berlin, in prep. In German with an English summary.

[15] Reinhardt, C., The contribution of decentralized measures for preventive flood protection in the Upper Flöha watershed (Central Ore Mountains), $\mathrm{PhD}$ thesis, Department of Earth Sciences Freie Universität Berlin, in prep. In German with an English summary.

[16] Ramelow, M.: The influence of landuse changes on the flood runoff generation in the Upper Flöha watershed - rainfall-runoff modelling WaSiM-ETH, PhD thesis, Department of Earth Sciences Freie Universität Berlin, in prep. In German with an English summary. 